\section{SPINAL EPIDURAL ANALGESIA}

By P. R. Bromage, M.B., B.S., F.F.A.R.C.S., D.A. Pp. vii + I23, with 4I illustrations. Edinburgh: E. \& S. Livingstone, Ltd. I954. I5s.

This book covers satisfactorily both the theoretical and practical aspects of spinal epidural analgesia, and derives from many years' study and an extensive practice of the method.

The author rightly stresses the need to employ one set method of identifying the subarachnoid space and to try and maintain a constant routine for the whole procedure.

The greatest disadvantage of epidural analgesia, namely, the length of time required for analgesia to develop, has now been largely overcome by the use of zylocaine, but only at the expense of duration of action as compared with nupercaine.

It is a matter of regret that ideal conditions are not obtained for thoracoplasty by epidural analgesia, in the author's experience.

Whether epidural analgesia will every wholly supplant subarachnoid block for those anaesthetists who only occasionally give spinal anaesthetics, is very doubtful, but all technical details are dealt with thoroughly and reliable guidance is given to anyone anxious to try the method. However, although spinal epidural analgesia has some definite advantages over subarachnoid block, it has its disadvantages too and also its own complications.

\section{C.A.C.}

\section{THE MECHANISM TOF INFLAMMATION}

Edited by G. JASMIN, M.D., and A. RoberT, M.D. Pp. 308, illustrated. Montreal: Acta Inc. 1953. 64s.

This book records the proceedings at a symposium, organized by Professor Selye and held on the occasion of the i 9 th International Physiological Congress in Montreal. The United Kingdom does not appear to have been represented among the participants. The papers and discussions reflect firstly the remarkable stimulus which recent studies of adrenal secretions have provided in this field of biology. Secondly, they reveal the current interest in the chemical approach to inflammation and the search for knowledge of the chemistry of normal connective tissue, without which the complex processes of reactions to injury cannot be interpreted. The monograph contains many references to recent work as well as an excellent subject index in the style which is now a familiar feature of publications from Professor Selye's department. It provides an important source of information and reference for those interested in inflammation in its diverse aspects.

R.R.H.L.

\section{TEXTBOOK OF MEDICINE}

Edited by Sir John Conybeare, K.B.E., M.C., D.M., F.R.C.P., and W. N. Mann, M.D., F.R.C.P. Eleventh edition. Pp. xvi +905 , with 40 illustrations. Edinburgh: E. \& S. Livingstone Ltd. I954. 37s. 6d.

' Conybeare,' that standby of so many students wanting a reasonably short textbook of medicine, is here in a new-this time the eleventh-edition. The two editors (for the last two editions, Sir John Conybeare has been assisted in his editorial task by Dr. W. N. Mann) are to be congratulated on keeping it short although, inevitably, it has grown with the years and now contains 25 per cent. more words than the original (1929) edition. In this new edition, the section on psychological medicine has been largely rewritten by Drs. Curran and Partridge. The section on endocrinology has also been extensively revised and the neurological section by Sir Francis Walshe has been revised by Dr. Denis Brinton. Dr. Maurice Cambell perhaps deserves special mention for bringing even the electrocardiographic ' $\mathrm{V}$ ' leads into a short textbook like this.

It is difficult to see how this book could be improved without greatly increasing its length an 65 so defeating the whole intention of the editors $\infty$ It is, in the reviewer's opinion, quite the best shorf textbook of medicine available and it is unreservedly recommended.

\section{'CONCERNING ANAESTHESIA'}

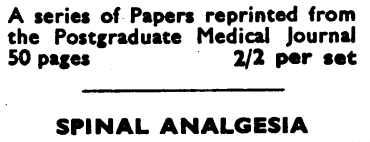

By William W. Mushin, M.A., M.B., B.A., F.F.A., R.C.S.

INHALATION ANAESTHESIA

By John Gillies, C.V.O., M.C., M.B., Ch.B., F.R.C.S.E., D.A.

A SYSTEM OF ANAESTHESIA USING CHEST SURGERY

By T. Cecil Gray, M.D., D.A., F.F.A., R.C.S.

ANALGESIA IN OBSTETRICS

By P. J. Helliwell, M.B., Ch.B., D.A., and A. Michael Hutton, M.R.C.S., L.R.C.P., D.A.

GENERAL ANAESTHESIA FOR DENTAL SURGERY

By W. S. McConnell, M.B., B.S., D.A.

REGIONAL ANAESTHESIA

By Alan Hune, D.M., M.Ch., F.R.C.S.

POST-OPERATIVE CARE

By John Beard, M.D. D.A.

Published by

THE

FELLOWSHIP OF postoraduate medicine 60 Portland Place, W.I 